\title{
Evaluation of physical, sensorial, and antioxidant properties of gluten-free bread enriched with Moringa Oleifera leaf powder
}

\author{
Hayat Bourekoua ${ }^{1,2} \cdot$ Renata Różyło $^{2}$ Urszula Gawlik-Dziki ${ }^{3}$ Leila Benatallah $^{1}$. \\ Mohammed Nasreddine Zidoune ${ }^{1} \cdot$ Dariusz Dziki $^{4}$
}

Received: 18 April 2017 / Revised: 8 June 2017 / Accepted: 24 June 2017 / Published online: 11 July 2017

(C) The Author(s) 2017. This article is an open access publication

\begin{abstract}
The aim of this study was to evaluate the effect of Moringa oleifera leaf powder addition on physical, sensorial, and antioxidant properties of gluten-free bread. Moringa leaf powder (MLP) was incorporated at different levels $(2.5,5.0,7.5$, and $10 \%$ in basic replacement) in gluten-free bread. The results revealed that addition more than $2.5 \%$ decreased the specific volume of bread. The hardness and chewiness of bread slightly decreased with 2.5 and $10 \%$ MLP addition, whereas springiness was not affected by MLP. For sensory evaluation, the most acceptable glutenfree bread was obtained for control bread and bread with 2.5\% MLP. The lightness of crumb and crust decreased with increasing of MLP from 63.37 to 27.59 and from 52.40 to 33.49 , respectively. The total phenolics content (TPC) and antioxidant activity of extracts increased with the addition of MLP. The addition of MLP already for $2.5 \%$ resulted in large increase in the content of TPC (from 0.88 to 2.12 GAE/g dw). The high activity for DPPH scavenging was found for $7.5 \%$ and for $10 \%$ of MLP addition. For ABTS scavenging capacity, the high activity was for 5.0, 7.5, and $10 \%$. Regarding RED and $\mathrm{OH}$ scavenging capacity,
\end{abstract}

Renata Różyło

renata.rozylo@up.lublin.pl

1 Institut de la Nutrition, de l'Alimentation et des Technologies Agro-Alimentaires (INATAA), Université des Frères Mentouri-Constantine 1, Route de Ain El-Bey, 25000 Constantine, Algeria

2 Department of Equipment Operation and Maintenance in the Food Industry, University of Life Sciences, Doświadczalna 44, 20-280 Lublin, Poland

3 Department of Biochemistry and Food Chemistry, University of Life Sciences, Skromna Street 8, 20-704 Lublin, Poland

4 Thermal Engineering Department, University of Life Sciences, 44 Doświadczalna St., 20-280 Lublin, Poland gluten-free breads with MLP from 2.5 to $10 \%$ presented significantly higher activity (RED from 32.92 to 21.56 and $\mathrm{OH}$ scavenging from 54.38 to $47.31 \mathrm{EC}_{50} \mathrm{mg} \mathrm{dw}$ comparing to control bread (40.02; $90.81 \mathrm{EC}_{50} \mathrm{mg} \mathrm{dw} / \mathrm{ml}$, respectively). Taking into account both the sensory evaluation and antioxidant activity, the addition of MFP should not exceed 5\%.

Keywords Bread making · Gluten-free bread · Moringa leaf $\cdot$ Physical properties $\cdot$ Antioxidant activity
Abbreviations
MLP Moringa leaf powder
TPC Total phenolics content
RED Reducing power

\section{Introduction}

Moringa oleifera commonly known as the miracle plant or the 'tree of life' is a plant native to India, but is cultivated throughout the world; it is a nutritious tree with a variety of potential uses [1-3]. Its leaves are an exceptional source of vitamin A, B group and C. Leaves are considered one of the best vegetable sources of minerals, their content of calcium, iron, and potassium are very high [4]. They are excellent sources of protein and contain very little fat and carbohydrates. They are an incomparable source of essential amino acids such as lysine, methionine, and cysteine often deficient in diets. Thus, making these leaves one of the best plant foods $[2,5,6]$.

Moringa oleifera leaves are rich in phytonutrients source such as carotenoids [3, 7], tocopherols, and ascorbic acid, it has also been found to contain appreciable amounts of total phenols and flavonoids which can be used as antioxidant [3, $8,9]$. 
In many parts of the world including Africa, the use of M. oleifera as a food fortificant is on the increase. Some studies have been conducted for the use of Moringa leaf powder as nutrient supplement of wheat bread, but there is no study concerning gluten-free bread with the addition of Moringa leaf $[4,9,10]$.

Gluten-free bread is often low in protein, minerals, and other nutrients in comparison with the traditional wheat bread $[11,12]$. Supplementation of gluten-free bread by Moringa leaf seems to be a good way to provide appropriate levels of minerals, protein, phenols, and other nutrients.

Over the world, the only proven treatment for coeliac disease is a strict and lifelong adherence to a gluten-free diet, which leads to the deficiency in nutrients components resulting none only from the intestinal abnormalities, but also from an insufficient supply of nutrients in gluten-free diet [13-16]. Patients showing nutritional deficiencies could require supplementation of their diets with vitamins, antioxidants, minerals, and proteins to correct deficiencies and restore nutrient reserves [17, 18]. Bourekoua et al. [19] reported that celiac disease suffers from the lack of glutenfree products with the subsequent negative effects on nutritional and health status of patients.

In the absence of study about gluten-free bread with additional Moringa leaf, its seems interesting to conduct this work to determine the effect of Moringa leaf powder addition on the physical, sensorial, and antioxidant properties of gluten-free bread.

\section{Materials and methods}

\section{Chemicals}

ABTS (2,2'-azino-bis (3-ethylbenzothiazoline-6-sulphonic acid), DPPH (2,2-diphenyl-1-picrylhydrazyl), Folin-Ciocalteau reagent, ammonium thiocyanate, Fe $\mathrm{SO}_{4}$, and sodium thiocyanate were purchased from SigmaAldrich company (Poznan, Poland). All others chemicals were of analytical grade.

\section{Raw materials}

Moringa Oleifera leaves powder (MLP) derived from India was purchased from Targroch (Filipowice, Poland) $(5.62 \%$ moisture, $27.85 \%$ fiber, $5.41 \%$ lipid, $23.29 \%$ protein, and $37.83 \%$ carbohydrates). Rice was obtained from MAKRO K \& K Sp. Z.o.o, Cmolas, Poland, rice semolina (particle size from 200 to $500 \mu \mathrm{m}$ ) was obtained by grinding rice ( $10.33 \%$ moisture, $0.22 \%$ ash, $0.50 \%$ lipid, and $7.80 \%$ protein content) and sieved (laboratory sifter Retsh, AS200, Germany). Field bean (Vicia faba) (10.46\% moisture, $0.50 \%$ ash, $1.03 \%$ lipid, and $30.86 \%$ protein) was purchased from Al-Amir Company (Albehera, Egypt). Field bean semolina (size from 200 to $500 \mu \mathrm{m}$ ) was obtained after grinding the hulled bean seeds. The grinding of rice and field bean was made using laboratory mill (LMN-100 TESTCHEM, Radlin, Poland). Instant dry yeast (SafInstant, France), salt, commercial sunflower oil, and fresh eggs were purchased from a local market.

\section{Preparation of gluten-free breads with MLP}

The gluten-free formula according to [20] included rice with supplemented field bean in a ratio of $2 / 1$ (w/w) was used in this study. Gluten-free breads ingredients consisted on $200 \mathrm{~g}$ of rice/field bean semolina, $4 \mathrm{~g}$ dry yeast, $4 \mathrm{~g}$ salt, $20 \mathrm{~g}$ fresh egg, $40 \mathrm{~g}$ sunflower oil, and $150 \mathrm{~g}$ of water determined according to preliminary trials of baking tests.

Four formulas were prepared with different levels of MLP: $2.5,5,7.5$, and $10 \%$ on rice/field bean semolina replacement basis, and a control bread was prepared with $0 \%$ levels of MLP. All ingredients were mechanically mixed with exception of fresh egg and MLP for $1 \mathrm{~min}$. After a resting time of $10 \mathrm{~min}$, the fresh egg and MLP were added and the mixture was kneaded (Kitchen Aid, Model 5KPM5-220-240 V 50/60 H-USA, St-Joseph, MI) for $15 \mathrm{~min}$ at $25^{\circ} \mathrm{C}$.

After kneading, the dough was divided into four portions (80 g), placed in molds and fermented in a climatic chamber (Sadkiewicz Instruments, Bydgoszcz, Poland) for $45 \mathrm{~min}$ at $37{ }^{\circ} \mathrm{C}$ (75-80\% of relative humidity). The baking test of fermented dough was carried out for $20 \mathrm{~min}$ at $230{ }^{\circ} \mathrm{C}$ in an electric oven (Sadkiewicz Instruments, Bydgoszcz, Poland). The loaves were left $1 \mathrm{~h}$ at room temperature for cooling before evaluation of their characteristics. For each levels, one batch of dough was prepared and four loaves of bread were baked for physical and biochemical characteristics For sensory evaluation, additional four batches (16 loaves) were prepared. Control gluten-free bread and gluten-free bread with different levels of MLP are shown in Fig. 1.

\section{Evaluation of physical properties of gluten-free breads}

Four loaves were used. Bread volume was measured by the millet seed displacement method [21]. The specific volume was calculated by dividing the bread volume by its weight.

Textural properties of bread crumb $(30 \times 30 \times 20 \mathrm{~mm})$ were measured using a texture analyzer (ZWICK Z020/ TN2S strength tester), and the samples were compressed twice using a capital equipped with a $30 \mathrm{~mm}$ plug until a $50 \%$ depth at a crosshead speed of $1 \mathrm{~mm} \mathrm{~s}^{-1}$ was achieved [22-25]. The parameters recorded were obtained from the TPA curves 1 and 2: hardness (peak force 1), springiness (length of the base of the area 2/length of the base of the 


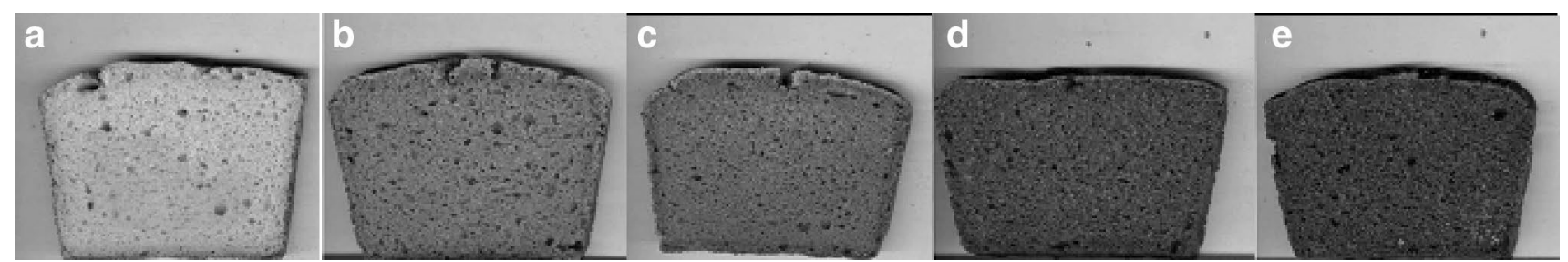

Fig. 1 Crumb appearance of gluten-free breads with MLP: $a, b, c, d$ gluten-free bread with 0, 2.5, 5.0, 7.5, and 10\% MLP, respectively

area 1), and chewiness (hardness $\times$ cohesiveness $\times$ springiness). Data from four replicate were averaged.

Color of bread crumb and crust was measured using a colorimeter (4Wave CR30-16) (Planeta, Tychy, Poland) under conditions (Light: D65; observer angle: $10^{\circ}$; space: LAB; diam: $16 \mathrm{~mm}$; style: 8/day). The color was determined in CIE- $L * a * b *$ system, where $L^{*}$ indicates lightness. The redness +/greenness - and the yellowness +/blueness - are denoted by $a^{*}$ and $b^{*}$ values, respectively. The total color difference $(\Delta \mathrm{E})$ was also determined as follows:

$\Delta E=\sqrt{(\Delta L)^{2}+(\Delta a)^{2}+(\Delta b)^{2}}$.

Data from three slices per sample were averaged.

\section{Total phenolics content and antioxidant properties}

\section{Extract preparation}

Dry samples of breads were ground to obtain powder. One gram of bread powder was extracted for $30 \mathrm{~min}$ with $5 \mathrm{ml}$ of methanol:water mixture $(1: 1, \mathrm{v} / \mathrm{v})$.

The extracts were separated by decantation in centrifuge for $15 \mathrm{~min}$. The residues were extracted again with $5 \mathrm{ml}$ of methanol and the extracts were combined and stored in darkness at $-20{ }^{\circ} \mathrm{C}$.

\section{Total phenolics content}

Total phenols were determined according to the Folin-Ciocalteu method [26]. For each sample, $0.1 \mathrm{ml}$ of extract was mixed with $0.1 \mathrm{ml}$ of distilled water, $0.4 \mathrm{ml}$ of Folin reagent $\left(1: 5 \mathrm{H}_{2} \mathrm{O}\right)$, and after $2 \mathrm{ml}$ of $10 \%, \mathrm{Na}_{2} \mathrm{CO}_{3}$ was added. The mixtures were kept at room temperature for $30 \mathrm{~min}$ before measuring the absorbance in spectrophotometer at a wavelength of $720 \mathrm{~nm}$. The total phenols were expressed in $\mathrm{mg}$ as gallic acid equivalents (GAE).

\section{Antioxidant activity}

Antioxidant activity (AA) of MLP and gluten-free breads was evaluated by four different methods: the DPPH radicals scavenging activity [27]. ABTS radical scavenging activity [28], reducing antioxidant power (RED) [29], and
$\mathrm{OH} \cdot$ scavenging assay [30] were performed. All activities were expressed as $\mathrm{EC}_{50}$-extract concentrate ion that provided $50 \%$ of activity based on a dose-dependent mode of action. $\mathrm{EC}_{50}$ value $(\mathrm{mg} / \mathrm{ml})$ is the effective concentration at which the absorbance was 0.5 for RED and was obtained by interpolation from linear regression analysis. The lower $\mathrm{EC}_{50}$ value indicates a higher antioxidant activity.

\section{Sensory evaluation}

For sensory evaluation, the whole bread was divided into eight parts (slices) and the two slices for a each consumer were taken [31]. The panel for sensory evaluation consisted of 52 untrained consumers (23-48 years, 28 females and 24 males) who were habitual consumers of bread. According to a nine-point hedonic scale (1: dislike extremely, 5: neither like nor dislike, and 9: like extremely), the taste, aroma, texture, and the overall acceptability of breads were evaluated [32].

\section{Statistical analysis}

Four loaves of bread were used. All the experiments were replicated in triplicate unless otherwise stated.

Data were averaged and means were compared and evaluated using one-way analysis of variance (ANOVA) followed by the Tukey's Significant Differences post hoc test, performed using the STATISTICA 7.0 software (StatSoft, Inc., Tulsa, OK, USA). A statistical difference at $p<0.05$ was considered significant.

\section{Results and discussion}

\section{Physical properties of gluten-free breads fortified with MLP}

Results of specific volume, textural parameters, and crumb and crust color of obtained breads are shown in Fig. 2 and Tables 1, 2.

Specific volume The mean values of specific volume of loaves shown in Fig. 1 indicated no difference 


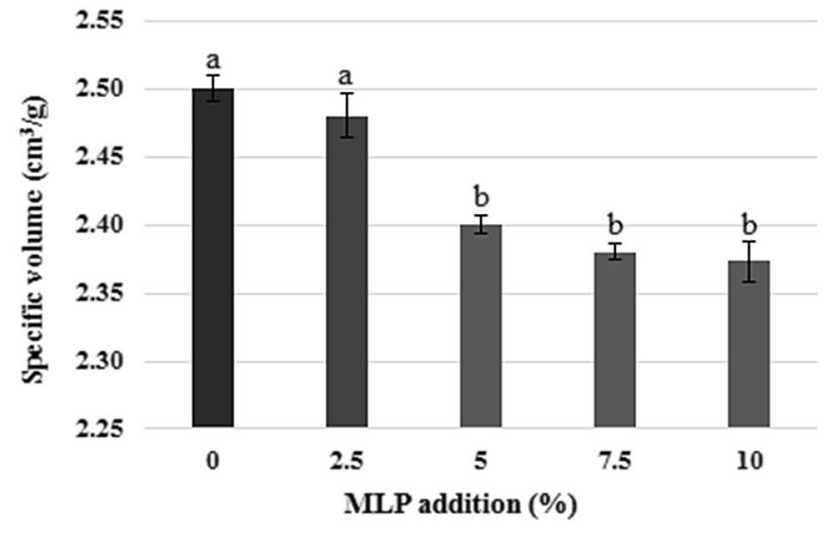

Fig. 2 Specific volume of gluten-free breads with MLP: $a, b$ indicated significant difference at 0.05 levels

between sample containing $2.5 \%$ of MLP $\left(2.48 \mathrm{~cm}^{3} / \mathrm{g}\right)$ and control bread $\left(2.50 \mathrm{~cm}^{3} / \mathrm{g}\right)$; a significant decrease of specific volume was observed when higher amount of MLP was added. These results are consistent with those previously published for wheat bread enriched with MLP $[4,9]$.

\section{Textural parameters}

As shown in Table 1, hardness of gluten-free breads was decreased significantly with increasing MLP from 0 to $5 \%$ comparing to control bread ( $25.30 \mathrm{~N})$. However, no significant effect was shown for bread with 7.5 and $10 \%$ of MLP on hardness of gluten-free breads in comparison with control bread. Comparing to control bread significant decrease was observed in chewiness of breads with addition MLP from 0 to $7.5 \%$. The addition of MLP had no significant influence on springiness of obtained breads.

\section{Color of bread}

Considering color, lightness $\left(L^{*}\right)$ of crumb and crust decreased significantly with increasing MLP addition (Table 2). The redness $\left(a^{*}\right)$ of crumb was increased with the addition of MLP from 2.36 to 4.14. The highest redness was marked for bread crumb with $7.5 \%$ of MLP, and there were no significant differences between $a^{*}$ value for 7.5 and $10 \%$. It could be caused by increasing the intensity of another color parameter with higher addition of MLP. Conversely, as shown in crust color, the addition of MLP from 0 to $10 \%$ decreased significantly this parameter from 13.99 to 6.37 . The yellowness $\left(b^{*}\right)$ of crumb increased significantly with the addition of MLP (from 22.62 to 27.28). However, the yellowness $\left(b^{*}\right)$ of crust decreased significantly with increasing MLP addition (from 35.20 to 23.06). The total color difference of crumb and crust $(\Delta E)$ significantly increased with MLP addition from 18.84 to 37.46 for crumb and from 14.44 to 25.14 for crust. The differences in color parameters of breads are caused by pigments in MLP. As reported by [33], MLP had a deep green color related to high chlorophyll content, and this green color of MLP changes the color of bread.

\section{Antioxidant properties}

The total phenolics content (TPC) and antioxidant activity (AA) of MLP and obtained breads are shown in Table 3. Showing results of phenolic compounds, MLP present the highest value of TPC with $33.13 \mathrm{mg} \mathrm{GAE} / \mathrm{g} \mathrm{dw}$. As reported by [34] analysis of hydro-methanolic extracts of Moringa, leaves revealed a wide range of phenolic compounds. Many authors also reported that the leaves of $M$. oleifera fresh or dried are known to be excellent source of antioxidants and they have significantly higher antioxidant content comparing to fruits such as strawberries known for high antioxidant contents [7, 35-37].

In general, all breads contain phenolics components. The addition of MFP significantly enriched gluten-free products with TPC from $0.88 \mathrm{mg}$ GAE/g dw for control bread to $2.39 \mathrm{mg} \mathrm{GAE} / \mathrm{g}$ dw for bread with $10 \%$ MFP. The addition of MFP already in the amount of $2.5 \%$ resulted in very large changes in the TPC from 0.88 to $2.12 \mathrm{GAE} / \mathrm{g} \mathrm{dw}$. Many authors reported that phenolics can form complexion with protein in matrix, and heating process also may alter phenolic antioxidants in bread during baking in different extents [38, 39].

In DPPH and ABTS radicals scavenging activity and for RED, the values were varied significantly for bread with different levels of MLP. The highest activities were found for bread with 7.5 and 10\% of MLP. Instead of RED, there were no significant differences between AA of breads with 5.0 and 7.5\% MLP. In general, breads with MFP had higher antioxidant activity compared to control bread. Breads with $2.5,5.0,7.5$, and $10.0 \%$ of MLP presented a significantly higher ABTS scavenging activity $\left(\mathrm{EC}_{50}=7.51,6.15\right.$, 5.89 , and $4.72 \mathrm{mg} \mathrm{dw} / \mathrm{ml}$ ) comparing to control bread with $\left(\mathrm{EC}_{50}=9.95 \mathrm{mg} \mathrm{dw} / \mathrm{ml}\right)$.

Scavenging of hydroxyl radicals is an important antioxidant activity because of very high reactivity of the $\mathrm{OH}$. radicals, enabling it to react with a wide range of molecules found in living cells, such as sugars, amino acids, lipids, and nucleotides [40]. Thus, removing this radicals is very important for the protection of living systems. The hydroxyl radicals scavenging potential of various extracts is shown in Table 3. The lowest activity was observed for control bread. $\mathrm{OH}$. radicals scavenging activity increased with increasing of MLP in bread recipe.

The highest activity was found for 7.5 and $10 \%$ of MLP addition, and these results were similar for the 
Table 1 Textural parameters of gluten-free breads with MLP

\begin{tabular}{lrrrrr}
\hline Parameters & \multicolumn{5}{l}{ Moringa leaves powder levels } \\
\cline { 2 - 6 } & \multicolumn{1}{c}{$0 \%$} & \multicolumn{1}{c}{$5 \%$} & \multicolumn{1}{l}{$5 \%$} & \multicolumn{1}{c}{$10 \%$} \\
\hline Hardness $(N)$ & $25.30 \pm 0.99 \mathrm{a}$ & $22.40 \pm 0.15 \mathrm{~b}$ & $23.02 \pm 1.28 \mathrm{~b}$ & $24.96 \pm 1.30 \mathrm{ab}$ & $26.04 \pm 1.72 \mathrm{a}$ \\
Chewiness $(N)$ & $6.39 \pm 0.14 \mathrm{a}$ & $4.75 \pm 0.18 \mathrm{~b}$ & $4.54 \pm 0.03 \mathrm{~b}$ & $4.43 \pm 0.58 \mathrm{~b}$ & $5.16 \pm 0.25 \mathrm{ab}$ \\
Springiness & $0.72 \pm 0.05 \mathrm{a}$ & $0.73 \pm 0.06 \mathrm{a}$ & $0.71 \pm 0.02 \mathrm{a}$ & $0.74 \pm 0.02 \mathrm{a}$ & $0.73 \pm 0.03 \mathrm{a}$ \\
\hline
\end{tabular}

Values in the same line not sharing same letters are significantly different $(p<0.05)$

\begin{tabular}{|c|c|c|c|c|c|}
\hline \multirow[t]{2}{*}{ Parameters } & \multicolumn{5}{|c|}{ Moringa leaves powder levels } \\
\hline & $0 \%$ & $2.5 \%$ & $5 \%$ & $7.5 \%$ & $10 \%$ \\
\hline \multicolumn{6}{|l|}{ Crumb color } \\
\hline$L^{*}$ & $63.3 \pm 1.97 a$ & $47.66 \pm 1.58 b$ & $40.21 \pm 0.63 c$ & $29.08 \pm 1.49 \mathrm{~d}$ & $27.59 \pm 0.34 d$ \\
\hline$a^{*}$ & $2.36 \pm 0.02 \mathrm{c}$ & $3.63 \pm 0.15 b$ & $3.45 \pm 0.04 b$ & $4.14 \pm 0.08 a$ & $3.99 \pm 0.08 \mathrm{a}$ \\
\hline$b^{*}$ & $22.62 \pm 0.29 c$ & $30.19 \pm 0.94 a b$ & $29.87 \pm 0.31 \mathrm{ab}$ & $31.89 \pm 2.51 \mathrm{a}$ & $27.28 \pm 0.47 b$ \\
\hline$\Delta E$ & - & $18.84 \pm 0.57 d$ & $26.54 \pm 0.54 c$ & $35.62 \pm 0.35 b$ & $37.46 \pm 0.60 \mathrm{a}$ \\
\hline \multicolumn{6}{|l|}{ Crust color } \\
\hline$L^{*}$ & $52.40 \pm 1.21 \mathrm{a}$ & $39.54 \pm 0.60 b$ & $39.77 \pm 0.48 b$ & $34.42 \pm 1.34 \mathrm{c}$ & $33.49 \pm 0.41 c$ \\
\hline$a^{*}$ & $13.99 \pm 0.38 \mathrm{a}$ & $12.48 \pm 0.08 b$ & $9.12 \pm 0.15 c$ & $6.87 \pm 0.52 \mathrm{~d}$ & $6.37 \pm 0.13 d$ \\
\hline$b^{*}$ & $35.20 \pm 0.14 a$ & $29.07 \pm 0.37 b$ & $28.08 \pm 0.94 b$ & $22.52 \pm 0.66 c$ & $23.06 \pm 0.11 \mathrm{c}$ \\
\hline$\Delta E$ & - & $14.44 \pm 0.33 b$ & $16.06 \pm 0.48 b$ & $25.76 \pm 0.49 a$ & $25.14 \pm 1.83 \mathrm{a}$ \\
\hline
\end{tabular}

Values in the same line not sharing same letters are significantly different $(p<0.05)$

\begin{tabular}{|c|c|c|c|c|c|}
\hline \multirow[t]{2}{*}{ Sample } & \multirow{2}{*}{$\begin{array}{l}\text { (mg GAE/g dw) } \\
\text { TPC }\end{array}$} & \multicolumn{4}{|l|}{$\mathrm{EC}_{50}(\mathrm{mg} \mathrm{dw} / \mathrm{ml})$} \\
\hline & & DPPH & ABTS & RED & $\mathrm{OH}$ \\
\hline M 0 & $0.88 \pm 0.00 \mathrm{e}$ & $25.97 \pm 4.41 \mathrm{a}$ & $9.95 \pm 0.21 \mathrm{a}$ & $40.02 \pm 1.36 \mathrm{a}$ & $90.81 \pm 6.91 \mathrm{a}$ \\
\hline M 2.5 & $2.12 \pm 0.02 \mathrm{c}$ & $31.62 \pm 7.00 \mathrm{a}$ & $7.51 \pm 0.16 b$ & $32.92 \pm 1.23 b$ & $54.38 \pm 2.81 \mathrm{c}$ \\
\hline M 5.0 & $2.03 \pm 0.04 \mathrm{~d}$ & $18.91 \pm 6.17 \mathrm{ab}$ & $6.15 \pm 0.09 c$ & $28.75 \pm 0.93 c$ & $59.14 \pm 0.39 b$ \\
\hline M 7.5 & $2.27 \pm 0.04 b$ & $12.22 \pm 4.80 \mathrm{bc}$ & $5.89 \pm 0.06 c$ & $23.46 \pm 2.17 \mathrm{~d}$ & $49.68 \pm 1.04 \mathrm{~d}$ \\
\hline M 10 & $2.39 \pm 0.10 b$ & $10.60 \pm 0.74 c$ & $4.72 \pm 0.09 \mathrm{~d}$ & $21.56 \pm 0.53 \mathrm{~d}$ & $47.31 \pm 2.52 \mathrm{~d}$ \\
\hline MLP & $33.13 \pm 2.39 \mathrm{a}$ & $1.23 \pm 0.47 \mathrm{~d}$ & $0.94 \pm 0.18 \mathrm{e}$ & $1.89 \pm 0.20 \mathrm{e}$ & $59.52 \pm 0.63 b$ \\
\hline
\end{tabular}

Values in the same column not sharing the same letters are significantly different $(p<0.05)$

$T P C$ total phenolics content, $D P P H$ ability to quench DPPH radicals, ABTS ability to quench ABTS radicals, $R E D$ reducing power, $O H$ ability to quench $\mathrm{OH}$ radicals, $M O, M 2.5, M 5, M 7.5, M 10$ control bread and bread with $2.5,5,7.5$ and $10 \%$ MLP addition, respectively, $M L P$ moringa leaf powder
Table 3 Total phenolics content and antioxidant activity of MLP and bread samples
Table 2 Color parameters of crumb and crust of gluten-free breads with MLP 
Table 4 Sensory evaluation of gluten-free bread enriched with MLP

\begin{tabular}{llllll}
\hline MLP addition (\%) & \multicolumn{5}{l}{ Sensory attributes } \\
\cline { 2 - 6 } & Taste & Aroma & Appearance & Texture & Overall \\
\hline 0 & $6.32 \pm 0.471 \mathrm{a}$ & $8.06 \pm 0.497 \mathrm{a}$ & $7.70 \pm 0.575 \mathrm{a}$ & $6.04 \pm 0.587 \mathrm{a}$ & $6.81 \pm 0.878 \mathrm{a}$ \\
2.5 & $6.04 \pm 0.517 \mathrm{~b}$ & $7.57 \pm 0.500 \mathrm{~b}$ & $7.06 \pm 0.718 \mathrm{~b}$ & $6.02 \pm 0.604 \mathrm{a}$ & $6.72 \pm 0.885 \mathrm{a}$ \\
5.0 & $5.66 \pm 0.474 \mathrm{c}$ & $6.55 \pm 0.641 \mathrm{c}$ & $6.74 \pm 0.660 \mathrm{~b}$ & $5.98 \pm 0.522 \mathrm{a}$ & $6.28 \pm 0.699 \mathrm{~b}$ \\
7.5 & $4.26 \pm 0.445 \mathrm{~d}$ & $5.55 \pm 0.503 \mathrm{~d}$ & $5.55 \pm 0.607 \mathrm{c}$ & $4.83 \pm 0.580 \mathrm{~b}$ & $5.09 \pm 0.450 \mathrm{c}$ \\
10 & $2.77 \pm 0.423 \mathrm{e}$ & $2.94 \pm 0.745 \mathrm{e}$ & $4.45 \pm 0.607 \mathrm{~d}$ & $4.74 \pm 0.445 \mathrm{~b}$ & $3.60 \pm 0.660 \mathrm{~d}$ \\
\hline
\end{tabular}

Values followed by the same letter in the same column are not significantly different $(p<0.05)$ aroma, and appearance was obtained for bread with $10 \%$ of MLP. The enrichment of bread with 2.5 and $5 \%$ of MLP had little influence of bread taste.

Regarding texture, there is no statistical difference with control gluten-free bread and bread with 2.5 and $5.0 \%$ of MLP. Results of overall acceptability showed that the highest value was found for control bread and bread with $2.5 \%$ of MLP against the lowest value for bread with $10 \%$ of MLP.

The lowest score for sensory attributes were obtained for bread with $10 \%$ of MLP. These can be related to the green color of the bread imparted by chlorophyll content of the MLP that affect negatively the acceptability of consumers.

\section{Conclusion}

In this study, different levels of MLP were chosen for partial replacement of formula based on rice/field bean semolina for gluten-free bread making process. The experiment results showed that gluten-free breads with higher level of MLP than 2.5\% had poor physicals characteristics (low specific volume, compact texture) comparing to control glutenfree bread $(p<0.05)$. Sensory evaluation showed that the addition of MLP at high level affects overall acceptability of bread, and an acceptable gluten-free bread was obtained with $2.5 \%$ of MLP addition. The addition of MLP to gluten-free bread results in decrease in yellowness of color of bread which appears greenish and dark and became more pronounced with increase in MLP addition. Most importantly, the addition of MLP significantly increased TPC and AA of obtained bread. Obtained results indicated that the addition of MLP to gluten-free bread improves its nutritional quality and presents, therefore, a good material for enriching gluten-free bread with bioactive components for coeliac patients.

Acknowledgements This research was funded by the exceptional National Program (PNE) from Algeria. H. Bourekoua acknowledges the financial support of Institut de la Nutrition, de l'Alimentation et des Technologies Agro-Alimentaires (INATAA). Experiments were also supported by the statutory funds of University of Life Science in Lublin, Poland.

\section{Compliance with ethical standards}

Conflict of interest There are no conflicts of interest to declare.

Compliance with ethics requirements This article does not contain any studies with human participants or animals performed by any of the authors.

Open Access This article is distributed under the terms of the Creative Commons Attribution 4.0 International License (http:// creativecommons.org/licenses/by/4.0/), which permits unrestricted use, distribution, and reproduction in any medium, provided you give appropriate credit to the original author(s) and the source, provide a link to the Creative Commons license, and indicate if changes were made.

\section{References}

1. Morton J (1991) The horseradish tree, Moringa ptergosperma (Moringaceae) - a boon to Arid Lands? Econ Bot 45(3):318-333

2. Mohammed Nour AA, Mohamed AR, Adiamo OQ, Babiker EE (2016) Changes in protein nutritional quality as affected by processing of millet supplemented with Moringa seed flour Moringa. J Saudi Soc Agric Sci. doi:10.1016/j.jssas.2016.05.006

3. Wang Y, Gao Y, Ding H, Liu S, Han X, Gui J, Liu D (2017) Subcritical ethanol extraction of flavonoids from Moringa oleifera leaf and evaluation of antioxidant activity. Food Chem 218:152-158

4. Sengev AI, Abu JO, Gernah DI (2013) Effect of Moringa oleifera leaf powder supplementation on some quality characteristics of wheat bread. Food Nutr Sci 4:270-275

5. Teye GA, Baffoe F, Teye M (2013) Effects of Moringa (Moringa oleifera) leaf powder and dawadawa (Parkia biglobosa), on sensory characteristics and nutritional quality of frankfurtertype sausages-a preliminary study. Global Adv Res J Agri Sci 2:029-033

6. Hekmat S, Morgan K, Soltani M, Gough R (2015) Sensory evaluation of locally-grown fruit purees and inulin fibre on probiotic yogurt in Mwanza, Tanzania and the microbial analysis of probiotic yogurt fortified with Moringa oleifera. J Health Popul Nutr 33:60-67

7. Saini RK, Shetty NP, Giridhar P (2014) Carotenoid content in vegetative and reproductive parts of commercially grown Moringa oleifera Lam. cultivars from India by LC-APCI-MS. Eur Food Res Technol 238:971-978

8. Vázquez-León LA, Páramo-Calderón DE, Robles-Olvera VJ et al (2017) Variation in bioactive compounds and antiradical activity of Moringa oleifera leaves: influence of climatic factors, tree 
age, and soil parameters. Eur Food Res Technol. doi:10.1007/ s00217-017-2868-4

9. Oyeyinka AT, Oyeyinka SA (2016) Moringa oleifera as a food fortificant: recent trends and prospects. J Saudi Soc Agric Sci. doi:10.1016/j.jssas.2016.02.002

10. Olaitan NI, Eke MO, Uja EM (2014) Quality evaluation of complementary food formulated from Moringa oleifera leaf powder and pearl millet (Pennisetum Glaucum) flou. Int J Eng Sci 3:59-63

11. Litwinek D, Ziobro R, Gambuś H, Sikora M (2014) Gluten free bread in a diet of celiacs. Int J Celiac Dis 2:11-16

12. Sabanis D, Tzia C, Papadakis S (2008) Effect of different raisin juice preparations on selected properties of gluten-free bread. Food Bioprocess Tech 1:374-383

13. Kiskini A, Kapsokefalou M, Yanniotis S, Mandala I (2012) Effect of iron fortification on physical and sensory quality of gluten-free bread. Food Bioprocess Tech 5:385-390

14. Krupa-Kozak U, Drabinska N (2016) Calcium in gluten-free life: health-related and nutritional implications. Rev. Foods 15:5. doi:10.3390/foods5030051

15. Vici G, Belli L, Biondi M, Polzonetti V (2016) Gluten free diet and nutrient deficiencies: a review. Clin Nutr 35:1236-1241

16. Wronkowska M, Haros M, Soral-Śmietana M (2013) Effect of starch substitution by buckwheat flour on gluten-free bread quality. Food Bioprocess Tech 6:1820-1827

17. Osella C, La Torre M, Sánchez H (2014) Safe foods for celiac people. Food Nutri Sci 5:787-800

18. Bascuñán KA, Vespa MC, Araya M (2016) Celiac disease: understanding the gluten-free diet. Rev Eur J Nutr. doi:10.1007/ s00394-016-1238-5

19. Bourekoua H, Benatallah L, Zidoune MN, Rosell CM (2016) Developing gluten free bakery improvers by hydrothermal treatment of rice and corn flours. LWT Food Sci Technol 73:342-350

20. Benatallah L, Zidoune MN, Michon C (2012) Optimization of HPMC and water addition for a gluten-free formula with rice and field bean based on rheological properties of doughs. Int Rev Chem Eng 4:474-481

21. AACC (2000) American Association of Cereal Chemists. Approved methods of the AACC (10th ed). American Association of Cereal Chemists, St Paul, USA

22. Różyło R (2014) Effect of process modifications in two cycles of dough mixing on physical properties of wheat bread baked from weak flour. Food Bioprocess Tech 7:774-783

23. Różyło R, Dziki D, Laskowski J, Skonecki S, Łysiak G, Kulig R, Różyło K (2014) Texture and sensory evaluation of composite wheat-oat bread prepared with novel two-phase method using oat yeast fermented leaven. J Texture Stud 45:235-245

24. Różyło R, Rudy S, Krzykowski A, Dziki D (2015) Novel application of freeze-dried amaranth sourdough in gluten-free bread production. J Food Process Eng 38:135-143

25. Różyło R, Dziki D, Gawlik-Dziki U, Cacak-Pietrzak G, Miś A, Rudy S (2015) Physical properties of gluten-free bread caused by water addition. Int Agrophysics 29:353-364

26. Singleton VL, Rossi JA (1965) Colorimetry of total phenolics witch phosphomolybdic-phodphotungstics acid reagents. Am J Enol Vitic 16:144-158

27. Brand-William W, Cuvelier E, Berset CM (1995) Use of free radical method to evaluate antioxidant activity. LWT-Food Sci Technol 28:25-30
28. Re R, Pellegrini N, Proteggente A, Pannala A, Yang M, RiceEvans C (1999) Antioxidant activity applying an improved ABTS radical cation decolorization assay. Free Radic Biol Med 6:1231-1237

29. Oyaizu M (1986) Studies on products of browning reactionantioxidative activities of products of browning reaction prepared from glucosamine. Jpn J Nutr 44:307-315

30. Su XY, Wanga ZY, Liu JR (2009) In vitro and in vivo antioxidant activity of Pinus koraiensis seed extract containing phenolic compound. Food Chem 117:681-686

31. Matos ME, Rosell CM (2012) Relationship between instrumental parameters and sensory characteristics in gluten-free breads. Eur Food Res Technol 235(1):107-117

32. Lim HS, Park SH, Ghafoor K, Hwang SY, Park J (2011) Quality and antioxidant properties of bread containing turmeric (Curcuma longa L.) cultivated in South Korea. Food Chem 124:1577-1582

33. Karim O, Kayode R, Oyeyinka S, Oyeyinka A (2015) Physicochemical properties of stiff dough 'amala' prepared from plantain (Musa Paradisca) flour and Moringa (Moringa oleifera) leaf powder. Food Health Dis 4:48-58

34. Nouman W, Anwar F, Gull T, Newton A, Rosa E, DomínguezPerles R (2016) Profiling of polyphenolics, nutrients and antioxidant potential of germplasm's leaves from seven cultivars of Moringa oleifera Lam. Ind Crops Prod 83:166-176

35. Moyo B, Oyedemib S, Masika PJ, Muchenje V (2012) Polyphenolic content and antioxidant properties of Moringa oleifera leaf extracts and enzymatic activity of liver from goats supplemented with Moringa oleifera leaves/sunflower seed cake. Meat Sci 91:441-447

36. Vongsak B, Sithisarn P, Mangmool S, Thongpraditchote S, Wongkrajang Y, Gritsanapan W (2013) Maximizing total phenolics, total flavonoids contents and antioxidant activity of Moringa oleifera leaf extract by the appropriate extraction method. Ind Crops Prod 44:566-571

37. Gopalakrishnan L, Doriya K, Kumar DS (2016) Moringa oleifera: a review on nutritive importance and its medicinal application. Food Sci Human Wellness 5:49-56

38. Sivam AS, Sun-Waterhouse D, Quek SY, Perera CO (2010) Properties of bread dough with added fiber polysaccharides and phenolic antioxidants: a review. J Food Sci 75:163-174

39. Gawlik-Dziki U, Świeca M, Dziki D, Sęczyk L, Zlotek U, Różyło R, Kaszuba K, Ryszawy D, Czyż J (2014) Anticancer and antioxidant activity of bread enriched with broccoli sprouts. Bio Med Res Int. doi:10.1155/2014/608053

40. Wang H, Gao XD, Zhou GC, Cai L, Yao WB (2008) In vitro and in vivo antioxidant activity of aqueous extract from Choerospondias axillaris fruit. Food Chem 106:888-895

41. Sowndhararajan K, Kang SC (2013) Free radical scavenging activity from different extracts of leaves of Bauhinia vahlii Wight and Arn. Saudi J Biol Sci 20:319-325

42. Gawlik-Dziki U, Świeca M, Dziki D, Baraniak B, Tomiło J, Czyż J (2013) Quality and antioxidant properties of breads enriched with dry onion (allium cepa L.) skin. Food Chem 138(2-3):1621-1628 